\title{
QUALITY EVALUATION OF CHEVON AS AFFECTED BY CARCASS DRESSING TECHNIQUES AND OPEN-AIR MARKET DISPLAY
}

\author{
Ebunoluwa Apata ${ }^{1}$, Oluwaseyi Eniolorunda ${ }^{1}$, Babatunde Omojola ${ }^{2}$, \\ Oluwakemi Apata ${ }^{3}$, Kehinde Adeyemi ${ }^{4}$ \\ ${ }^{I}$ Meat Science Laboratory, Department of Animal Production, Olabisi Onabanjo University, \\ Ayetoro Campus, P.M.B. 0012, Ayetoro, Ogun State, Nigeria \\ ${ }^{2}$ Meat Science Laboratory, Department of Animal Science, University of Ibadan, \\ Ibadan, Oyo State, Nigeria \\ ${ }^{3}$ Hospitality and Tourism Unit, Department of Wildlife and Ecotourism Management, \\ University of Ibadan, Ibadan, Oyo State, Nigeria \\ ${ }^{4}$ National Productivity Centre, Federal Secretariat, Ibadan, Oyo State, Nigeria \\ ebunoluapata2008@yahoo.com
}

\begin{abstract}
A b s t r a c t: This study investigated the effects of post-mortem carcass dressing techniques and open market retail display on the quality and acceptability of goat meat. Twenty-seven Red-Sokoto bucks were used. They were slaughtered, weighed and randomly allocated to 3 post-slaughter dressing techniques: scalding, skinning and singeing. The primal cuts were displayed for $0,3,6$ and 9 hours. Visual colour, proximate composition, $\mathrm{pH}$, lipid oxidation, microbial load and sensory characteristics of the meat from the 3 treatments were determined and data collected were subjected to analysis of variance (ANOVA) in a completely randomized design with $3 \times 4$ factorial arrangement, and the significant means separated at $\mathrm{p}<0.05$. The visual colour and protein were higher in singed meat, moisture was higher in skinned meat and decreased against the time of display. Lipid oxidation and microbial load values were higher in skinned meat; aerobic bacteria were higher than lactic acid bacteria, and increased against the time of display. All the sensory attributes and acceptability scores decreased against the time of display except tenderness. In conclusion, carcass dressing techniques and open market retail display affected goat meat quality and acceptability. Singeing technique could be adopted since it furnished higher meat quality and acceptability and goat meat must not be displayed beyond 6 hours.
\end{abstract}

Keywords: acceptability; carcass dressing techniques; goat meat; open market display; quality

\section{ЕВАЛУАЦИЈА НА КВАЛИТЕТОТ НА КОЗЈО МЕСО КАКО РЕЗУЛТАТ НА ВЛИЈАНИЕТО НА РАЗЛИЧНИ ТЕХНИКИ НА ОБРАБОТКАТА НА ТРУПОТ ВО УСЛОВИ НА ТРГОВИЈА НА ОТВОРЕН ПАЗАР}

А п с т р а к т: Во овој труд се претставени резултатите од истражувањата на влијанието на техниките за обработка на трупови на козите по колењето и на нивната изложеност на отворен пазар врз квалитетот и прифатливоста на козјото месо. Во истражувањата беа користени дваесет и седум кози од расата Red-Sokoto. Тие беа заклани, измерени и по случаен избор распределени за 3 техники на обработка на трупот по колењето: шурење, отстранување на кожата (дерење) и опрлување. Примероците месо беа оставени на отворено $0,3,6$ и 9 часа. Визуелно беше определена бојата, приближно беа детерминирани хемискиот состав, рН вредноста, оксидацијата на мастите, присутноста на микроорганизмите, како и сензорните карактеристики на месото од трите третмани. Добиените податоци беа обработени со анализа на варијација (ANOVA), со целосно случаен избор на примерокот со распоред $3 \times 4$ и значајните средни вредности беа поделени на $p<0,05$. Визуелните вредностит на бојата и содржината на протеини беа повисоки кај примероците обработени со техниката на опрлување на месото, додека влагата покажуваше повисока застапеност кај примероците месо обработени со техниката на отстранување на кожата и се намалуваше пропорционално со времето на стоење на месото на отворено. Оксидацијата на мастите и застапеноста на микроорганизми беа повисоки кај примероците месо обработени со техниката на дерење, застапеноста на аеробните бактерии беше поголема во однос на млечно- 


\begin{abstract}
киселинските бактерии и нивната вредност се зголемуваше со текот на времето. Вредностите за сите сензорни особини се намалуваа со зголемување на времето на стоење на месото на отворено пропорционално со времето на изложеноста, со исклучок на мекоста. Заклучок: Различните техники на обработката на трупот и продажбата на месото на отворено влијаат врз квалитетот и прифатливоста на козјото месо. Техниката прлење обезбедува повисок квалитет и прифатливост на месото, а козјото месо не би требало да се изложува на отворено подолго од 6 часа.
\end{abstract}

Клучни зборови: прифатливост; техники на обработка; козјо месо; изложеност на отворен пазар; квалитет

\section{INTRODUCTION}

Goat meat (chevon) is becoming widely a consumed red meat and enjoys great popularity in many developing countries especially in Asia, Africa, Far East and the Americas [1]. Meat from farmed animals must be attractive and satisfying the palate of consumers and once the meat is purchased, cooked and served, it should meet the expectations of the consumers in terms of eating qualities [2]. Meat is sold while displayed in the open by retailers in $\mathrm{Ni}$ geria and in most developing countries. The open display of meat needs to be evaluated for safety and sensory appeal such as meat healthiness and palatability [3]. It has been reported that following exsanguination of meat animals, the process of converting muscle to meat begins and thereafter, meat is subjected to degradation by chemical, physical, enzymatic and microbiological reactions over processing and through distribution channels without refrigeration [4]. Considerable losses had been incurred on meat and fish because of flaws in the handling and distribution of these food items in the market [5]. Spoilage is any change in the natural state of food including meat, that reduces its desirability either for aesthetic or health reasons during display, sales or storage [6]. Therefore, meat, whether fresh or processed for human consumption, should get to consumers in an acceptable form. Other vital factors that affect meat immediately after bleeding and during display for sales until it gets to table is the method of dressing carcasses. In their report [7], noted that the three post-mortem dressing methods, namely scalding, skinning and singeing, could affect the temperature and $\mathrm{pH}$ as well as physical, chemical and eating quality of meat. This study was therefore carried out to investigate the effects of post-mortem carcass dressing and open market display on the quality and acceptability of goat meat.

\section{MATERIALS AND METHODS}

A total of 27 Red-Sokoto bucks of $10-12$ months old, weighing $18-29 \mathrm{~kg}$, were purchased from Bodija market and transported to the Department of Animal Science, University of Ibadan where this study was carried out. They were stabilized for 2 weeks with a standard diet, fasted for 16 hours, stunned and bled [8].

\section{Dressing of carcasses}

The carcasses of bled bucks were weighed and randomly allotted to each of the post-mortem dressing method, 3 carcasses to each dressing treatment thus: $\mathrm{T} 1=$ scalding, $\mathrm{T} 2=$ skinning, $\mathrm{T} 3=$ singeing.

Scalding: It was carried out by modifying the method of [9]; by pouring hot water at $70^{\circ} \mathrm{C}$ on each carcass to soften the hairs which were scrapped with a metal scrapper.

Skinning: It was done with a sharp knife. A ring was made round one of the hind legs just above the hock. The knife was inserted under the skin of the leg to open it up to the root of the tail. Another incision was made from the pelvic region up to the neck. The skin was gradually pulled until it was removed completely according to [7].

Singeing: It was effected on the carcasses in this group by flaming them over burning fire $\left(250^{\circ} \mathrm{C}\right.$ ) made with hard wood teak (Tectona grandis) until all the hairs were carefully burnt off with minimal rupture of the skin following the procedures of [8].

\section{Evisceration and fabrication of carcasses}

The carcasses were shanked, eviscerated, washed and fabricated into primal cuts as described by [10].

\section{Retail display of raw meat}

The fabricated primal cuts from each treatment were displayed on a clean table beside the road between the Department of Animal Science and Faculty of Veterinary Medicine to simulate open market retail situation according to [5] and [11]. Students and staff in both the Animal Science Department and Veterinary Medicine and the passersby were invited to mimic meat buyers. They 
touched and felt the meat, then talked directly facing the meat as if they were bargaining for the price as obtained in the open retail markets in Nigeria and other developing countries. Meat samples were removed from the thigh cut after display at intervals of 3 hours for evaluation of meat quality parameters.

\section{Colour of displayed meat}

The colour of raw meat displayed was determined visually following the procedures of [12]. The meat samples were removed from displayed thigh cuts at $0,3,6$ and 9 hours for colour evaluation on a scale ranging from 1 to 8 with higher score representing a more homogenous red colour.

\section{Lipid oxidation}

The oxidation of displayed meat was determined following the procedures of [13]. A $50 \mathrm{~g}$ meat sample of unrendered fat from thigh cut from each treatment of $0,3,6$ and 9 hours was ground in a blender (Plate $5 \mathrm{~mm}$ ) Model 242, Nakai, Japan, for 25 seconds and extracted with $30 \mathrm{ml}$ of ice cold (3.2 v/v acetic acid: chloroform). The extraction was swirled vigorously and $0.5 \mathrm{ml}$ saturated potassium iodide $\left(83.2 \mathrm{KI} / 40 \mathrm{ml} / \mathrm{H}_{2} \mathrm{O}\right)$ was added and mixed thoroughly. $30 \mathrm{ml}$ of distilled water was added and the mixture was allowed to stand for 5-10 minutes at room temperature. The mixture was titrated with $0.01 \mathrm{M}$ sodium thiosulphate $\left(\mathrm{Na}_{2} \mathrm{~S}_{2} \mathrm{O}_{3}\right)$ gradually with vigorous shaking. During titration, $0.5 \mathrm{ml}$ starch indicator (starch $1 \%$ + chloroform $0.3 \%$ ) was added. When the colour of the lower organic layer remained yellow, the sample was vigorously swirled and was allowed to stand for an additional 10 minutes. The end point of the titration was established when the colour of the upper aqueous layer disappeared. The modified peroxide value $(m P V)$ of meat samples was calculated with the formula:

$$
m P V=\frac{(S)(N)(1000)}{W},
$$

where:

$$
\begin{aligned}
& m P V=\text { modified peroxide value } \\
& S=\text { ml of } \mathrm{Na}_{2} \mathrm{~S}_{2} \mathrm{O}_{3} \\
& N=\text { normality of } \mathrm{Na}_{2} \mathrm{~S}_{2} \mathrm{O}_{3}(0.01) \\
& W=\text { weight of sample (g of fat) }
\end{aligned}
$$

\section{Proximate composition and $\mathrm{pH}$ of displayed meat}

The proximate composition of the displayed meat removed at $0,3,6$ and 9 hours - moisture, crude protein, ether extract (fat) and ash content, was carried out following the procedures of [13], while the $\mathrm{pH}$ of the meat samples removed at $0,3,6$ and 9 hours was determined according to the method of [14]. $10 \mathrm{~g}$ of meat sample was homogenized for 5 minutes with $90 \mathrm{ml}$ of distilled water using a laboratory blender (Plate $5 \mathrm{~mm}$ ) Model 242, Nakai, Japan. The meat $\mathrm{pH}$ was taken with a portable $\mathrm{pH}$ meter (Model H18424 Micro-computer, Havanna Instruments, Romania).

\section{Microbiological properties of displayed meat}

$10 \mathrm{~g}$ of meat samples from displayed leg cut were removed at $0,3,6$ and 9 hours aseptically with a pair of forceps and blended with $90 \mathrm{ml}$ of $0.1 \%$ $(\mathrm{w} / \mathrm{v})$ peptone water for 60 seconds with a blender (Plate $5 \mathrm{~mm}$ ) Model 242 Nakai, Japan, following the procedures of [15], [16] and [13]. $1 \mathrm{ml}$ of undiluted homogenate of each sample was spread on duplicate Petri plates after additional dilutions were made in $0.1 \%$ peptone water $(\mathrm{w} / \mathrm{v})$. Bacteria numbers were determined from colony plates, and counts were obtained thus: Aerobic plate counts on plate count Agar (DIFCO, USA) incubated at $32^{\circ} \mathrm{C}$ for 48 hours; Enterobacteriaceae (coliform) on violet Red Bile Glucose Agar (DIFCO, USA) and overlaid with the same medium and incubated at $37^{\circ} \mathrm{C}$ for 24 hours; Lactic acid bacteria on lactobacilli MRS broth Bacto Agar and glacial acetic acid (pancreae) incubated at $32^{\circ} \mathrm{C}$ or 48 hours in an incubator. All the colony forming organisms were counted and expressed in cfu/g of samples.

\section{Organoleptic properties displayed meat}

The sensory evaluation of displayed meat for 0, 3, 6 and 9 hours was carried out using a 10-member semi-trained taste panel following the procedures of [17]. The taste panellists were drawn from the students and staff in the Department of Animal Science, University of Ibadan, in the age range of 19-35 years. They were provided unsalted cracker biscuits and bottled water in between treatment meat samples. Meat samples were coded before and after boiling for 20 minutes in labelled polythene bags to an internal temperature of $72^{\circ} \mathrm{C}$ doneness. The meat samples were presented sequentially to the panellists on a clean saucer and were evaluated independently of the other. The panellists rated the meat samples on a 9-point hedonic scale on which 1 $=$ disliked extremely and $9=$ liked extremely for colour, flavour, tenderness, juiciness, texture and overall acceptability. 


\section{Experimental design and statistical analysis}

A completely randomized design (CRD) with $3 \times 4$ factorial arrangement ( 3 treatments $\times 4$ periods of time) was employed in this study. The collected data were analyzed using [18] while the significant means were separated with Duncan multiple range test of the same software at $p=0.05$.

\section{RESULTS AND DISCUSSION}

The results of visual colour scores of the displayed Red-Sokoto buck meat as affected by post slaughter dressing methods are presented on Table 1.

\section{Table 1}

Visual colour scores of displayed Red-Sokoto buck meat as affected by scalding, skinning and singeing dressing methods and period of market display

\begin{tabular}{cc}
\hline \hline Parameter & Visual colour \\
\hline Treatments & \\
Scalding & $6.00 \pm 0.57^{\mathrm{b}}$ \\
Skinning & $5.00 \pm 0.88^{\mathrm{c}}$ \\
Singeing & $7.00 \pm 0.17^{\mathrm{a}}$ \\
Display time (hr) & \\
0 & $7.00 \pm 0.11^{\mathrm{a}}$ \\
3 & $6.00 \pm 0.47^{\mathrm{b}}$ \\
6 & $6.00 \pm 0.70^{\mathrm{b}}$ \\
9 & $5.00 \pm 0.86^{\mathrm{c}}$ \\
\hline \hline a, b, Means on the same column with different superscripts \\
are statistically significant $(\mathrm{p}<0.05)$.
\end{tabular}

Singeing treatment furnished the highest $(p<$ $0.05)$ visual colour score (7.00) followed by scalding, while skinning gave the least $(p<0.05)$ score (5.00). The colour intensity was very high $(p<0.05)$ on 0 hour (7.00) and decreased as the time of display increased and the colour was reduced $(p<0.05)$ to 5.00 score at 9 th hour. The results of visual colour of displayed Red-Sokoto buck raw meat showed that there was significant difference in the colour of the meat dressed with scalding, skinning and singeing with the latter having the highest colour intensity score while the meat from skinned carcasses had the least. This result could be due to high temperature and $\mathrm{pH}$ which tended to stabilize the colour of the meat from singed and scalded carcasses, probably the oxygen consuming enzymes present in the meat were relatively rendered inactive such that little surface oxygenation of myoglobin occurred as reported by [19]. There was high colour intensity for meat displayed at 0 hour probably due to oxidizing myoglobin when the meat samples were fabricated afresh thereby giving rise to a bright red colour intensity perhaps because of blooming. There was decrease in the visual colour of displayed goat meat starting from 3 hours to 9 hours which could be attributed to browning of the meat as a result of conversion of myoglobin to met-myoglobin [1]. Decrease in raw meat visual colour was more significant in skinned meat than in other two treatments and it was higher in singed meat perhaps due to high temperature and $\mathrm{pH}$ of singed meat which tended to stabilize the colour of singed and scalded meat samples. Probably, the oxygen consuming enzymes present in the meat were relatively rendered inactive such that little surface oxygenation of myoglobin occurred [19].

The proximate composition and $\mathrm{pH}$ results of the displayed meat are shown in Table 2 .

Skinning method elicited the highest $(p<0.05)$ meat moisture followed by scalding method and the least $(p<0.05)$ in singeing method. The increased singeing treatment furnished the highest $(p<0.05)$ crude protein, while skinning gave the lowest $(p<$ $0.05)$, and scalding treatment furnished the highest $(p<0.05)$ fat, and skinning the least $(p<0.05)$. There were no significant $(p>0.05)$ differences in the ash content and $\mathrm{pH}$ values of the meat samples across the treatments. The moisture content was higher $(p<0.05)$ but similar on $6^{\text {th }}$ and $9^{\text {th }}$ hours of display, while it was lower $(p<0.05)$ on 0 hours of display. On the other hand, crude protein was higher $(p<0.05)$ on 0 and 3 hours of display but decreased $(p<0.05)$ at $6^{\text {th }}$ and $9^{\text {th }}$ hours. However, there were no significant $(p>0.05)$ differences in the values of fat, ash and $\mathrm{pH}$ throughout the display time across the three treatments. Moisture content was higher in skinned goat meat displayed than in singed and scalded meat. The significant difference in moisture content between skinned and singed or scalded meat could be due to the fact that during singeing and scalding, juices could have been lost from the carcasses during the process, but skinned meat did not pass through heat (fire) nor hot water, therefore maintained normal range of moisture of meat for mammals [20]. Also, it was observed that moisture content of meat samples decreased across the three treatments during display as the time increased. This could be due to weep that occurs during meat display. It was reported by [21] that weep could be as high as 1 to $10 \mathrm{ml}$ per kilogramme of meat displayed in the first 48 hours for steaks or chops which could 
be 10 times greater. This phenomenon could lead to lower water holding capacity, increase in shear force value and reduced meat colour. The results from this study showed that singed meat followed by scalded meat had higher values of protein, while skinned meat had lower. This could be that protein coagulates when heat is applied to the meat [22] than when the carcass was skinned which was contrary to the report of [7] who reported high protein for skinned meat of rabbit. The protein in the meat decreased as the time of display increased perhaps as a result of weep in form of juice in which protein could have been siphoned out of the meat as report- ed by [23]. The results of fat content in goat meat obtained in this study showed that skinned meat had higher fat content than both singed and scaled meat samples. This could be to the fact that most of the subcutaneous fats would have been removed with the skin during skinning thereby leaving lower fat values. However, fat values were not significantly affected during retail display of the meat as observed in this study. There were no significant differences in the values of both ash and $\mathrm{pH}$ of meat between the treatments and during the retail display time of meat, perhaps dressing techniques and retail display of meat did not have effect on the meat.

Table 2

\section{Proximate composition and $\mathrm{pH}$ of Red-Sokoto buck meat as affected by post-slaughter dressing} and period of market display.

\begin{tabular}{|c|c|c|c|c|c|}
\hline \multirow{2}{*}{ Parameter } & \multicolumn{5}{|c|}{ Variable $(\%)$} \\
\hline & $\mathrm{MC}$ & $\mathrm{CP}$ & $\mathrm{EE}$ & Ash & $\mathrm{pH}$ \\
\hline \multicolumn{6}{|l|}{ Treatments } \\
\hline Scalding & $70.20 \pm 0.39^{\mathrm{b}}$ & $20.53 \pm 0.33^{c}$ & $3.17 \pm 0.10^{\mathrm{a}}$ & $1.53 \pm 0.01$ & $6.3 \pm 0.07$ \\
\hline Skinning & $76.33 \pm 0.74^{a}$ & $19.47 \pm 0.35^{\mathrm{b}}$ & $1.41 \pm 0.11^{\mathrm{b}}$ & $1.50 \pm 0.01$ & $6.5 \pm 0.09$ \\
\hline Singeing & $68.25 \pm 0.60^{\mathrm{c}}$ & $21.65 \pm 0.20^{\mathrm{a}}$ & $2.60 \pm 0.16^{\mathrm{ab}}$ & $1.60 \pm 0.03$ & $6.7 \pm 0.05$ \\
\hline \multicolumn{6}{|c|}{ Display time (hr) } \\
\hline 0 & $75.80 \pm 1.58^{c}$ & $20.81 \pm 0.84^{\mathrm{a}}$ & $3.21 \pm 0.36$ & $1.55 \pm 0.04$ & $6.3 \pm 0.04$ \\
\hline 3 & $75.67 \pm 1.86^{\mathrm{b}}$ & $20.62 \pm 0.95^{\mathrm{b}}$ & $3.19 \pm 0.34$ & $1.50 \pm 0.03$ & $6.5 \pm 0.05$ \\
\hline 6 & $74.56 \pm 1.75^{\mathrm{a}}$ & $19.50 \pm 0.96^{\mathrm{c}}$ & $3.00 \pm 0.30$ & $1.47 \pm 0.03$ & $6.5 \pm 0.05$ \\
\hline 9 & $73.45 \pm 1.60^{\mathrm{a}}$ & $19.35 \pm 0.80^{\mathrm{c}}$ & $2.91 \pm 0.29$ & $1.40 \pm 0.05$ & $6.6 \pm 0.03$ \\
\hline
\end{tabular}

${ }_{\mathrm{a}, \mathrm{b}, \mathrm{c}}$ Means on the same column with different superscripts are statistically significant $(p>0.05)$;

$\mathrm{MC}=$ Moisture content $\mathrm{CP}=$ Crude protein; $\mathrm{EE}=$ Ether extract.

Table 3 represents the results of lipid oxidating Red-Sokoto buck meat displayed for 0, 3, 6 and 9 hours.

Skinning treatment furnished the highest $(p<$ $0.05)$ value of rancidity $0.35 \mathrm{mEq}$, followed by scalding treatment $(0.25 \mathrm{mEq})$ and the least $(p<$ $0.05)$ in singeing $(0.22 \mathrm{mEq})$. the rancidity values increased $(p<0.05)$ as the period of meat display increased from 0 hour with $0.35 \mathrm{mEq}$ to $0.37 \mathrm{mEq}$ at 9 hours.

The value of lipid oxidation was higher in skinned meat than in scalded and singed meat samples, but there was no significant difference in the values of lipid oxidation in meat during the time of retail display. The results of lipid oxidation obtained in this study were not in line with the report of [1], who reported significant increase in lipid oxidation values for goat meat during the first three days of meat display. Probably, the time of display in this study was not as prolonged as in the case the authors reported. Lipid oxidation values of scalded and singed meat samples were not as high as those of skinned meat probably because of heat applied to scalded and singed carcasses which tended to stabilize and reduce the rate of fat decomposition in the meat samples which was contrary to the skinned meat samples that furnished high fat decomposition to form aldehydes and ketones as secondary products which produced undesirable rancid flavour [24]. The amount of lipid oxidation values however in this study did not exceed the $5 \mathrm{ppm}$ of TBA reported by [25]. 
Table 3

\section{Lipid oxidation of Red Sokoto buck meat as affected by post-slaughter dressing and market display}

\begin{tabular}{cc}
\hline \hline Parameter & Lipid oxidation $(\mathrm{mEq})$ \\
\hline Treatments & \\
Scalding & $0.25 \pm 0.11^{\mathrm{b}}$ \\
Skinning & $0.35 \pm 0.09^{\mathrm{a}}$ \\
Singeing & $0.22 \pm 0.10^{\mathrm{b}}$ \\
Display time (hr) & \\
0 & $0.33 \pm 0.12$ \\
3 & $0.35 \pm 0.11$ \\
6 & $0.35 \pm 0.11$ \\
9 & $0.37 \pm 0.04$ \\
\hline \hline
\end{tabular}

${ }^{a, b, c}$ Means on the same column with different superscripts are statistically significant $(p<0.05)$.

The results of microbial load of Red-Sokoto buck meat displayed for $0,3,6$ and 9 hours are shown in Table 4.

Table 4

Microbial load of Red-Sokoto buck meat
as affected by post-slaughter dressing
and period of market display

\begin{tabular}{cccc}
\hline \multirow{2}{*}{ Parameter } & \multicolumn{3}{c}{ Variable (cfu/g) } \\
\cline { 2 - 4 } & AEB & ETB & LAB \\
\hline Treatments & & \\
\hline Scalding & $5.71 \times 10^{4 \mathrm{ax}}$ & $4.60 \times 10^{3 \mathrm{bx}}$ & $3.52 \times 10^{3 \mathrm{cy}}$ \\
Skinning & $6.73 \times 10^{4 \mathrm{ax}}$ & $5.67 \times 10^{3 \mathrm{bx}}$ & $4.60 \times 10^{3 \mathrm{cx}}$ \\
Singeing & $4.17 \times 10^{4 \mathrm{az}}$ & $3.15 \times 10^{3 \mathrm{bz}}$ & $2.10 \times 10^{3 \mathrm{cz}}$ \\
\hline Display time $(\mathrm{hr})$ & & \\
\hline 0 & $4.26 \times 10^{4} \mathrm{ax}$ & $3.18 \times 10^{3} \mathrm{by}$ & $2.49 \times 10^{3 \mathrm{bz}}$ \\
3 & $4.62 \times 10^{4 \mathrm{ax}}$ & $4.22 \times 10^{3 \mathrm{ax}}$ & $3.20 \times 10^{3 \mathrm{by}}$ \\
6 & $5.70 \times 10^{4 \mathrm{ax}}$ & $4.65 \times 10^{3 \mathrm{by}}$ & $3.63 \times 10^{3 \mathrm{cz}}$ \\
9 & $5.78 \times 10^{4 \mathrm{ax}}$ & $4.70 \times 10^{3 \mathrm{by}}$ & $4.67 \times 10^{3 \mathrm{by}}$ \\
\hline \hline
\end{tabular}

ax, bx, cy, az bz cz Means on the same row or column with different superscripts are statistically significant $(p>0.05)$; AEB $=$ Aerobic bacteria, ETB $=$ Enterobacteria, $\mathrm{LAB}=$ Lactic acid bacteria.

Skinning treatment attracted the highest $(p<$ $0.05)$ microbes, followed by scalding and singeing being the least $(p<0.05)$. The aerobic bacteria were higher $(\mathrm{p}<0.05)$ in number than both the enterobacteria and lactic acid bacteria which had the least ( $p$ $<0.05)$ number. The aerobic bacteria were lower $(p$ $<0.05)$ but similar at 0 and 3 hours of meat display and increased $(p<0.05)$ at $6^{\text {th }}$ and $9^{\text {th }}$ hours with similar counts, also enterobacteria and lactic acid bacteria were lower $(p<0.05)$ in count at 0 hour and increased $(p<0.05)$ at 3 to 6 hours and further increased $(p<0.05)$ at 9 hours of display. Microbial status of displayed goat meat showed that skinned meat had higher microbial load within the treatments, while aerobic bacteria value was the highest among the treatment variables. Lower value of microbes observed in singed and scalded meat samples could be due to application of heat to carcasses during dressing which might have aided reduction of microbial count [26]. The high number of aerobic bacteria could be due to the fact that they could survive mostly in abundant oxygen since in the open market display there was oxygen in the air that could be laden with aerobic bacteria [27]. The aerobic bacteria started to increase in number after 6 hours of display enterobacteria after 3 hours of display while the lactic acid bacteria increased after 9 hours of display, however, the increase in the count of these microbes was not as high as $10^{7} \mathrm{cfu} / \mathrm{g}$ at which rate meat could be considered to be spoiled or unwholesome [25].

The results of sensory characteristics of displayed Red-Sokoto buck meat are represented on Table 5.

Singeing method furnished the highest $(p<$ 0.05 ) colour, aroma, flavour, tenderness, juiciness and overall acceptability scores followed by scalding, while skinning had the least $(p<0.05)$. The meat texture score was the highest $(p<0.05)$ in skinning treatment followed by scalding and singeing elicited the least $(p<0.05)$ score. The colour of the meat decreased $(p<0.05)$ steadily from 0 to 9 hours while aroma, flavour, juiciness, texture and overall acceptability scores were higher at 0 hour and scores were the same at 3 and 6 hours, of display and decreased between hours of 6 and 9 with lower score, but tenderness scores were lower $(p<0.05)$ at 0 and 3 hours and increased between 6 and 9 hours with similar scores. The singed meat was scored higher in colour by taste panellists than meat samples of scalded and skinned meat samples probably due to black-red colouration that was high in singed carcasses and it was reported as normal colour of goat meat [28]. The colour decreased as the time of retail display increased confirming the report of [29] that meat changes colour during long display which could also be manifested when the 
meat is cooked and since colour is the most important criterium consumers use to evaluate meat quality and acceptability, skinned meat and meat samples displayed for longer time would attract lower values for acceptability. The meat aroma and flavour scores were high for singed meat probably because of the impact of volatile compounds from the woods during singe-ing which furnished smoking flavour precursors on the meat. However, the aroma and flavour of goat meat decreased as the time of retail display increased perhaps due to the fact that most of the volatile molecules could have drained out as weep from the meat during waiting for display.

Table 5

Sensory characteristics' scores of Red-Sokoto buck goat meat as affected by post-slaughter dressing and period market display.

\begin{tabular}{cccccccc}
\hline \hline \multirow{2}{*}{ Parameter } & \multicolumn{7}{c}{ Variable } \\
\cline { 2 - 7 } & Col. & Arm. & Flv. & Tdn. & Jcn. & Tex. & O.A. \\
\hline Treatment & & & & & & \\
Scalding & $6.24 \pm 0.44^{\mathrm{b}}$ & $4.43 \pm 0.54^{\mathrm{c}}$ & $4.76 \pm 0.65^{\mathrm{c}}$ & $5.94 \pm 0.59^{\mathrm{b}}$ & $6.78 \pm 0.65^{\mathrm{b}}$ & $6.68 \pm 0.69^{\mathrm{b}}$ & $6.54 \pm 0.69^{\mathrm{c}}$ \\
Skinning & $5.17 \pm 0.78^{\mathrm{c}}$ & $5.60 \pm 0.40^{\mathrm{b}}$ & $5.85 \pm 0.64^{\mathrm{b}}$ & $4.86 \pm 0.64^{\mathrm{b}}$ & $5.73 \pm 0.61^{\mathrm{c}}$ & $7.71 \pm 0.68^{\mathrm{a}}$ & $5.23 \pm 0.64^{\mathrm{b}}$ \\
Singeing & $7.49 \pm 0.39^{\mathrm{a}}$ & $6.72 \pm 0.16^{\mathrm{a}}$ & $6.91 \pm 0.60^{\mathrm{a}}$ & $6.78 \pm 0.76^{\mathrm{a}}$ & $7.86 \pm 0.60^{\mathrm{a}}$ & $5.41 \pm 0.81^{\mathrm{c}}$ & $7.65 \pm 0.55^{\mathrm{a}}$ \\
Display time (hr) & & & & & & \\
0 & & & & & & & \\
3 & $5.8 \pm 0.53^{\mathrm{a}}$ & $5.86 \pm 0.81^{\mathrm{a}}$ & $6.98 \pm 1.03^{\mathrm{a}}$ & $4.78 \pm 0.99^{\mathrm{b}}$ & $6.88 \pm 1.01^{\mathrm{a}}$ & $5.89 \pm 1.01^{\mathrm{a}}$ & $8.16 \pm 0.75^{\mathrm{a}}$ \\
6 & $5.57 \pm 0.84^{\mathrm{b}}$ & $5.54 \pm 0.93^{\mathrm{a}}$ & $6.86 \pm 1.02^{\mathrm{a}}$ & $4.85 \pm 1.03^{\mathrm{b}}$ & $6.76 \pm 1.03^{\mathrm{a}}$ & $5.78 \pm 0.99^{\mathrm{a}}$ & $7.10 \pm 0.92^{\mathrm{b}}$ \\
9 & $5.42 \pm 0.85^{\mathrm{b}}$ & $4.51 \pm 0.87^{\mathrm{b}}$ & $5.70 \pm 1.03^{\mathrm{b}}$ & $5.87 \pm 1.02^{\mathrm{a}}$ & $5.72 \pm 1.04^{\mathrm{b}}$ & $4.67 \pm 1.05^{\mathrm{b}}$ & $7.00 \pm 0.96^{\mathrm{b}}$ \\
\hline \hline
\end{tabular}

${ }^{\mathrm{a}, \mathrm{b}, \mathrm{c}}$ Means on the same column with different superscripts are statically significant $(p>0.05)$. Col. $=$ Colour; Arm. $=$ Aroma; Flv. $=$ Flavour; Tdn. $=$ Tenderness; Jcn. $=$ Juiciness; Tex. $=$ Texture; O.A. $=$ Overall acceptability .

Meat tenderness scores were higher in singed and scalded meat perhaps as a result of effect of heat which might have partially reduced the toughness of the meat connective tissues including the cartilages and tendons which culminated in the high juiciness score of both singed and scalded meat, whereas the texture scores of both meat samples were reduced compared to that of skinned meat which was higher. The displayed meat became tenderer as the time of display increased perhaps due to natural tenderizing enzymes like cathepsin in the meat that reduced the connective tissues. The results from this study were at variance with the report of [3] that meat cuts from carcasses within 24 hours were less tender until after several days. Probably, the meat used in this study was from goat and not from cattle. The juiciness scores were higher in both singed and scalded meat than in skinned meat samples which did not agree with the report of [7], who found no difference in the juiciness of meat samples from scalded, skinned and singed rabbit carcasses which could be due to breed difference. Meat juiciness is related to meat wetness as a result of fluid from meat during chewing as well as the stimulating effect of intramuscular fat that builds up in the tongue, therefore, fat content of cooked meat would reflect on the juiciness score, thus a well marbled meat would be juicier [30] and [31]. The results of overall acceptability showed that most of the taste panellists preferred and accepted singed meat more than skinned and scalded meats which could be due to the high colour, aroma, flavour, tenderness and juiciness of singed meat [32, 33].

\section{CONCLUSION}

From the results of this study, it can be concluded that both carcass dressing techniques and open market retail display had significant influence on the quality and acceptability of goat meat. It was also confirmed that singeing technique furnished higher meat quality and acceptability factors. It is therefore recommended that singeing techniques be adopted and goat meat should not be played beyond 6 hours for high quality and consumers' acceptability. 


\section{REFERENCES}

[1] Galipali, S. K., Gadiyaram, M., Konakou, B., Pringle, T. D., Kannan, G.: Oxidative stability of chevon as influenced by dietary Tasco Supplementation in Boar goat bucks, South African Journal of Animal Science, Vol. 34, No. 1, pp. 171-173 (2004).

[2] Aberle, E. D., Forest, J. C., Gerrard, D. E., Mills, E. W.: Principles of Meat Science, Kendall-Hunt Publishing, 2001.

[3] Dinh, T., and Nhat, T.: Meat quality: Understanding of meat tenderness and influence of fat content on meat flavour. Journal of Science and Technology Development, Vol. 9, No. 12, pp. 65-70 (2006).

[4] FAO: Manual on Meat Cold Store Operations and Management: Agriculture and Consumer Protection, Food and Agricultural Organization (FAO) Corporate Document Repository, FAO, Rome, 2007.

[5] Eniolorunda, O. O., Adekunmisi, A. A., Olopade, O. A., Badaru, A. G., Taiwo, I. O.: Quality changes associateed with the marketing of some frozen fishes in Ogun State, Nigeria, Journal of Resources in Agriculture, Vol. 3, No. 2, pp. 41-45 (2006).

[6] FAO: Slaughtered of Livestock. In: Heinz, G., Srisuvan, T., (ed.,), Guidelines for Human Handling, Transport and Slaughter of Livestock, Food and Agricultural Organization (UN), Rome, 2001.

[7] Omojola, A. B., Adesehinwa, A. O. K.: Meat characterristics of scalded, singed and conventionally dressed rabbit carcasses, World Journal of Zoology, Vol. 1, No. 1, pp. 24 29 (2006).

[8] Okubanjo, A.O.: Meat characteristics of singed and conventionally dressed chevon carcasses, Journal of Food Science and Technology, vol. 34, No. 6, pp. $494-497$ (1997).

91] Monin, G., Talmant, A., Aillery, R., Collas, G.: Effects of carcass weight and meat quality of pigs dehaired by scalding or singeing post-mortem, Meat Science, Vol. 39, pp. 247-254 (1995).

[10] Attah, S.: Live performance, carcass and offal characteristics of goats slaughtered at different weights, Ph.D. thesis (in English), Department of Animal Science, University of Ibadan, Ibadan, Oyo State, Nigeria. 1997.

[11] Eneji, C. A., Ikepene, C. E., Ubua, J.: Effect of refrigeration and frozen storage on the shelf life of beef purchased from local markets and abattoir in Calabar metropolis, Nigeria, Pakistan Journal of Nutrition, Vol. 6, No. 6, pp. 576-581 (2007).

[12] AMSA.: Meat Colour Measurement Guidelines, American Meat Science Association, 2012.

[13] AOAC.: Official Methods of Analysis. $19^{\text {th }}$ Edition, AOAC International Inc. Washington D.C., 2000.

[14] Marchiori, A. F., De Felicio, P. E.: Quality of wild boar meat and commercial pork, Science Agric. (Piracicaba, Braz), Vol. 60, No. 1, pp. 1-10 (2003).

[15] ICMSF.: Microorganisms in Food - II: Sampling for Microbiological Analysis, Principles and Specific Application, $2^{\text {nd }}$ ed., University of Toronto Press, 1986.

[16] APHA.: Compendium of Method for the Microbiological Examination of Foods, $3^{\text {rd }}$ ed., American Public Health Association. Vanderzant C. and Splitlstoesser, D. F. (eds), Ann Arbor, Michigan, 1992.
[17] AMSA.: Research Guidelines for Cookery. Sensory Evaluation and Instrumental Tenderness Measurements of Meat, American Meat Science Association, 2015.

[18] SAS.: Statistical Analysis System. SAS Stat. Version 9, SAS Institute Inc., Garry NC, USA, 2002.

[19] Lindah, G.: Effect of low temperature preservation on the quality of vacuum packaged dry cured ham: Refrigerated frozen ham cuts: Colour characteristics of fresh pork, Ph.D. Thesis (in English), Swedish University of Agricultural Science Uppsala, Sweden. 2005.

[20] Lawrie, R. A.: Meat Science, $6^{\text {th }}$ Edition, Pergamon Press Ltd., Oxford, England, UK, 1998.

[21] MTU.: The Causes of Drips in Meat, Meat Technology Update, Food Science Australia, 2002.

[22] Aduku, A. O. and Olukosi, J. O.: Animal Products Processing and Handling in the Tropics, Living Books Series. GU Publication, Abuja, Nigeria, pp. 24-32, 2000.

[23] MMPC.: Ingredients in processed meat products: Basic chemistry of meat. Montana Meat Processors Convention, April 27-29, pp. 1-20, 2001.

[24] Gray, J. I., Pearson, A. M.: Lipid derived off flavour in meat information and inhabitation. In: Flavour of Meat and Meat Products, $1^{\text {st }}$ ed., Chapman and Hall, London, UK, 1994.

[25] Insausti, K., Berian, M.J., Purroy, A., Alberti, P., Lizaso, L., Herzander, B.: Colour stability of beef from different Spanish native cattle breeds stoned under vacuum and modified atmosphere, Meat Science, Vol. 53, pp. 241-249 (2006).

[26] Ukah, O. G., Omojola A. B., Ogunsola, O. O., Okubanjo, A. O.: Carcass and meat characteristics of grasscutter (Thryonomys Swiniderianus), Tropical Journal of Animal Science, Vol. 9, No. 1, pp. 31-38 (2006).

[27] Mikami, M.: Meat Processing and Meat Preservation. In: Manual of Meat Inspecting for Developing Countries, Food and Agricultural Organization (FAO), Annual Production and Health, Paper No. 119, Rome, Italy, 1994.

[28] Babiker, S. A., Elkhider, I. A., Shafie, S. A.: Chemical composition and quality attributes of goat and lamb meat, Meat Science, Vol. 28, pp. 273-277 (1990).

[29] Kannan, G., Kouakou., B., Gelaye., S.: Colour changes reflecting myoglobin and lipid oxidation in chevon cuts during refrigeration display, Small Ruminant Resources, Vol. 42, pp. 67-75 (2001).

[30] Aduku, A. O., Aganga, A. A., Dim, N. T., Okoh, P. N.: The effects of different methods of processing rabbits on carcass yield and quality, Journal of Applied Rabbit Resources, Vol. 9, No. 4, pp. 164-168 (1986).

[31] Lachowicz, K., Sobczak, M., Gajowiecki, L., Zych, A.: Effect of massaging time on texture, rheological properties and structure of three pork ham muscles, Meat Science, Vol. 63, pp. 225-233 (2003).

[32] Okubanjo, A. O.: Meat for Nigeria's Millions, Faculty Lecture Series Number 3. Faculty of Agriculture and Forestry, University of Ibadan, Oyo State, Nigeria, 1990.

[33] Wheeler, T. L., Koohmaraie, M., Cumdiff, L. V., Dikeman, M. E.: Effects of cooking and shearing methodology on variation in Warner-Bratzler shear force values in beef, Journal of Animal Science, Vol. 72, pp. 2325 - 2350 (1994). 